\title{
PENGARUH VARIASI TANAMAN BARIER SEBAGAI NATURAL PEST CONTROL TERHADAP POPULASI HAMA DAN PRODUKTIVITAS PADI
}

\section{(THE EFFECT OF BARRIER PLANT VARIATION AS NATURAL PEST CONTROL ON PEST POPULATION AND RICE PRODUCTION)}

\author{
Tien Aminatun, Budiwati, Lili Sugiyarto, Amin Khusnadiyah, Anisa Setya Hidayah \\ dan Ema Imtihana
}

Fakultas Matematika dan Ilmu Pengetahuan Alam Universitas Negeri Yogyakarta

Jl. Colombo No. 1 Yogyakarta 55281

email: tien_aminatun@uny.ac.id

\begin{abstract}
Abstrak
Tujuan dari penelitian ini adalah untuk menganalisis pengaruh variasi jenis tanaman barier terhadap dinamika populasi serangga hama pada tanaman padi dan produktivitas tanaman padi. Penelitian ini dilakukan di Kebun Percobaan Fakultas Pertanian UGM Banguntapan Bantul. Variabel bebas dari penelitian ini adalah perlakuan variasi tanaman barier yaitu kontrol (tanpa barier), gulma alami, bunga matahari, dan bunga kenikir. Variabel terikatnya adalah dinamika populasi serangga hama dan produktivitas tanaman padi. Pengamatan serangga hama dan musuh alaminya dilakukan terbatas pada pagi hari antara pukul 08.00-11.00 dengan metode scan sampling yang dilakukan pada 3 minggu sekali. Data produktivitas tanaman padi yang diambil meliputi berat kering gabah hasil panen per plot perlakuan. Untuk melihat pengaruh perlakuan variasi jenis tanaman barier terhadap populasi serangga hama tanaman padi dan produktivitas tanaman padi dilakukan uji ANOVA. Hasil penelitian menunjukkan tidak terdapat perbedaan yang signifikan dari pengaruh variasi jenis tanaman barier terhadap perbedaan dinamika populasi serangga hama maupun terhadap produktivitas tanaman padi, tetapi perlu diadakan penelitian lanjutan yang dikaitkan dengan variabel lain yang mempengaruhi produktivitas tanaman padi.

Kata kunci: tanaman barier, hama, musuh alami

Abstract
This study was aimed at analyzing the effect of the barrier plant variation to the population dynamic of rice pest insect and on rice crop productivity. The study was conducted in the experimental Garden of Faculty of Agriculture of Gadjah Mada University in Banguntapan Bantul. The independent variable was the treatment of barrier plant variation, i.e. control (without barrier), natural weed, sunflower and kenikir flower plants, while the dependent variables were population dynamic of pest insect and rice crop productivity. Pest insects and their natural enemies observation was carried out in between $08.00-11.00$ am by scan sampling every 3 weeks. The retrieval of crop productivity data was done when the harvest per treatment plot. The data obtained was then tested with ANOVA, to find out the effect of the treatments on population dynamic of rice crop pest, as well as rice crop productivity. The results show that there was no significant difference in the effect of barrier plant variation to the differences in population dynamic of pest insects; as well as in the productivity of rice crop, but it is necessary to conduct advanced research that is associated with other variables that affect rice crop productivity.
\end{abstract}

Keywords: barrier plants, pests, natural enemies 


\section{PENDAHULUAN}

Tanaman padi merupakan tanaman penting di Indonesia karena merupakan penghasil makanan pokok bagi sebagian besar masyarakat Indonesia. Dalam budidaya tanaman padi banyak jenis serangga hama yang menyerang sehingga mengurangi produktivitas atau hasil panen. Selama ini pengendalian hama banyak dilakukan dengan aplikasi pestisida sintetik yang berdampak negatif bagi lingkungan dan kesehatan. Dengan meningkatnya kesadaran dari banyak kalangan masyarakat, maka mulai dilakukan pengendalian hama yang lebih ramah lingkungan, salah satunya adalah dengan pengendalian hama secara alami.

Pengendalian hama secara alami (natural pest control) adalah pengendalian hama yang dilakukan dengan pendekatan ekologis (ecological approach) yang mengoptimalkan kerja ecosystem service (jasa ekosistem) dalam mengendalikan populasi hama, salah satunya adalah dengan tanaman barier yang memungkinkan interaksi multitrofik antara tanaman-tanaman utama, hama, musuh alami, dan berbagai jenis tanaman sekunder yang berfungsi sebagai tanaman barier tersebut (Parolin et al., 2012). Jadi, tanaman barier atau sering juga disebut sebagai tanaman refugia adalah tanaman yang ditanam di sekeliling lahan pertanian tanaman utama, yang diharapkan berfungsi sebagai tanaman perangkap bagi hama sehingga diharapkan dapat mengurangi populasi hama yang menyerang tanaman utama tersebut.

Hasil penelitian Erdiansyah dan Putri (2018) pada pertanaman padi sawah menyimpulkan bahwa penggunaan refugia kenikir (Cosmos caudatus) dan bunga kertas (Zinnia elegans) dapat meningkatkan jumlah musuh alami dan menekan partumbuhan populasi hama wereng hijau poppy (Nipothetix spp). Kurniawati (2015) juga telah memublikasikan hasil penelitiannya yang menemukan bahwa kehadiran tumbuhan berbunga dapat meningkatkan keragaman dan kelimpahan artropoda musuh alami pada tanaman padi gogo sehingga dapat menekan populasi serangga hama.

Tanaman perangkap selain berfungsi sebagai inang alternatif bagi hama, juga dapat berfungsi menarik serangga musuh alami dan polinator untuk datang. Hasil penelitian Mustakim, Leksono, dan Kusuma (2014) menunjukkan bahwa adanya blok tanaman refugia Ageratum conyzoides, Ageratum hostionun, Commelina difussa, dan Capsicum frutescens pada pertanaman apel, mempengaruhi komposisi jenis dan indeks keanekaragaman serangga polinator yang mengunjungi pertanaman apel tersebut.

Horgan et al. (2016) telah menguji coba potensi 13 jenis tanaman untuk digunakan dalam rekayasa ekologi, beberapa di antara- 
nya adalah kacang hijau, kacang panjang, dan bunga matahari. Tanaman ini ditanam di lokasi pematang sawah dan dipantau selama perkembangan tanaman padi. Tanaman ini kemudian dikenal dengan nama tanaman refugia, yaitu suatu area yang ditumbuhi beberapa jenis tumbuhan yang dapat menyediakan tempat perlindungan, sumber pakan atau sumberdaya yang lain bagi musuh alami seperti predator dan parasitoid. Setelah diamati ternyata tanaman refugia memiliki pengaruh terhadap keanekaragaman dan kelimpahan musuh alami. Pemanfaatan tanaman refugia memberikan dampak positif terutama terhadap pengendalian hama.

Berdasar latar belakang, perlu dilakukan penelitian bagaimanakah pengaruh variasi jenis tanaman barier terhadap dinamika populasi serangga hama dan musuh alaminya pada tanaman padi, dan bagaimana pengaruh variasi jenis tanaman barier terhadap produktivitas tanaman padi. Oleh karena itu, tujuan dari penelitian ini adalah untuk menganalisis pengaruh variasi jenis tanaman barier terhadap dinamika populasi serangga hama dan musuh alaminya pada tanaman padi serta pengaruh variasi jenis tanaman barier terhadap produktivitas tanaman padi.

\section{METODE PENELITIAN}

Penelitian ini merupakan penelitian eksperimen dengan rancangan acak lengkap 1 faktorial, yaitu variasi jenis tanaman barier pada pertanaman padi. Masing-masing perlakuan terdiri atas 3 plot ulangan, dengan luas setiap plot adalah $1 \times 1 \mathrm{~m}^{2}$. Setiap plot berisi masing-masing 16 tanaman padi dengan jarak tanam $20 \mathrm{~cm}$. Di sekeliling plot tanaman padi ditanami dengan tanaman barier dengan jarak dari tepi plot adalah $20 \mathrm{~cm}$, sedangkan pada plot kontrol tanpa tanaman barier di sekelilingnya. Tanaman barier yang digunakan adalah tanaman kenikir, bunga matahari, dan gulma yang tumbuh alami. Jarak antar plot adalah 2 meter. Penempatan plot-plot perlakuan dilakukan secara acak dengan kode-kode sebagai berikut: P1 untuk perlakuan tanpa tanaman barier dan pinggiran bersih dari gulma (kontrol), P2 untuk perlakuan dengan barier gulma tumbuh alami, P3 untuk perlakuan barier tanaman bunga matahari, dan P4 untuk perlakuan barier tanaman bunga kenikir.

Penelitian ini dilakukan di Kebun Percobaan Fakultas Pertanian UGM Banguntapan Bantul. Variabel bebas dari penelitian ini adalah perlakuan variasi tanaman barier, sedangkan variabel terikatnya adalah dinamika populasi serangga hama dan produktivitas tanaman padi (hasil panen). Sebagai variabel tambahan adalah faktor mikroklimatik dan edafik.

Bahan yang digunakan dalam penelitian ini adalah bibit tanaman padi, bibit tanaman kenikir, bunga matahari, dan 
pupuk organik. Alat-alat yang digunakan adalah peralatan bertani pada umumnya, insect net, thermometer udara, hygrometer, anemometer, lux-meter, soil tester, buku identifikasi serangga atau arthropoda, dan kamera.

Dalam penelitian ini dibuat 3 plot ulangan untuk masing-masing perlakuan, yaitu 3 plot ulangan untuk perlakuan tanpa tanaman barier dan pinggiran bersih dari gulma sebagai kontrol (kode P1-a, P1-b, P1-c), 3 plot untuk perlakuan dengan barier gulma tumbuh alami (kode P2-a, P2-b, P2c), 3 plot ulangan untuk perlakuan barier tanaman bunga matahari (kode P3-a, P3b, P3-c), dan 3 plot untuk perlakuan barier tanaman bunga kenikir (kode P4-a, P4b, P4-c). Jarak antarplot adalah 2 meter. Penempatan plot-plot perlakuan dilakukan secara acak.

Bibit padi dengan varietas gogo Inpago Unsoed 1 ditanam dalam plot dengan jarak tanam $20 \mathrm{~cm}$. Pemeliharaan tanaman padi dilakukan seperti cara-cara yang dilakukan oleh petani pada umumnya, yang meliputi pengairan, pemupukan, penyiangan, dan pemantauan. Pemupukan dilakukan 3 kali, yaitu 10 hari setelah tanam, 1 bulan setelah tanam, dan 2 bulan setelah tanam. Penyiangan dilakukan setiap satu minggu sekali dan penyiraman dilakukan 2 kali setiap minggu dengan sistem leb (lahan direndam dalam waktu 30 menit). Pemeliharaan ini dilakukan oleh seorang petani yang disewa khusus untuk kepentingan penelitian ini.

Pengamatan serangga hama dan musuh alaminya dilakukan terbatas pada pagi hari, yaitu antara pukul 08.00-11.00 dengan metode scan sampling (Martin \& Bateson 1993). Pengambilan data arthropoda dilakukan 3 minggu sekali. Data kandungan hara tanah didapat dari hasil analisis sampel tanah yang diambil pada bulan ke-3 setelah tanam. Analisis sampel tanah dilakukan di Laboratorium Balai Penelitian Tanaman Pangan (BPTP) Maguwoharjo Depok Sleman DIY. Pengambilan data produktivitas tanaman dilakukan saat panen yaitu dengan menimbang berat kering gabah per plot perlakuan.

Data yang diperoleh kemudian diuji beda dengan ANOVA, untuk melihat pengaruh perlakuan variasi jenis tanaman barier terhadap dinamika populasi serangga hama tanaman padi, serta produktivitas tanaman padi.

\section{HASIL DAN PEMBAHASAN}

Jenis-jenis serangga hama dan musuh alaminya dalam tingkatan takson familia yang ditemukan pada tajuk tanaman padi di plot-plot perlakuan disajikan pada Tabel 1 . Berdasar Tabel 1 diketahui bahwa terdapat 13 familia serangga hama dan 10 familia musuh alaminya yang ditemukan selama 1 musim tanam. Jenis hama dan musuh 
Tabel 1

Jenis-jenis Serangga Hama dan Musuh Alaminya dalam Tingkatan Takson Familia yang Ditemukan pada Tajuk Tanaman Padi di Plot-plot Perlakuan

\begin{tabular}{|c|c|c|c|c|c|}
\hline \multirow{2}{*}{ No } & \multirow{2}{*}{ Familia } & \multicolumn{4}{|c|}{ Frekuensi Kehadiran dalam 1 Musim Tanam } \\
\hline & & P1 & $\mathrm{P} 2$ & $\mathrm{P} 3$ & P4 \\
\hline & Serangga Hama & & & & \\
\hline 1 & Delphacidae & 11 & 9 & 4 & 9 \\
\hline 2 & Acrididae & 8 & 10 & 5 & 3 \\
\hline 3 & Thyreocoridae & 34 & 17 & 38 & 14 \\
\hline 4 & Chrysomelidae & 0 & 0 & 1 & 0 \\
\hline 5 & Alydidae & 3 & 2 & 0 & 0 \\
\hline 6 & Coreidae & 1 & 0 & 0 & 0 \\
\hline 7 & Pentatomidae & 0 & 1 & 0 & 0 \\
\hline 8 & Crambidae & 4 & 1 & 1 & 3 \\
\hline 9 & Lycanidae & 3 & 0 & 0 & 0 \\
\hline 10 & Scarabidae & 2 & 3 & 0 & 1 \\
\hline 11 & Carabidae & 0 & 3 & 0 & 0 \\
\hline 12 & Curculionidae & 0 & 0 & 0 & 1 \\
\hline \multirow[t]{4}{*}{13} & Drosophilidae & 0 & 2 & 0 & 0 \\
\hline & Jumlah Familia & 8 & 9 & 5 & 6 \\
\hline & Frekuensi Kehadiran Hama & 66 & 48 & 49 & 31 \\
\hline & Serangga Musuh Alami & & & & \\
\hline 1 & Formicidae & 22 & 12 & 14 & 13 \\
\hline 2 & Tomicidae & 1 & 1 & 1 & 0 \\
\hline 3 & Arachnidae & 1 & 0 & 1 & 1 \\
\hline 4 & Coccinelidae & 4 & 2 & 3 & 2 \\
\hline 5 & Staphylinidae & 0 & 1 & 0 & 1 \\
\hline 6 & Libellulidae & 0 & 0 & 1 & 0 \\
\hline 7 & Gryllidae & 2 & 1 & 1 & 0 \\
\hline 8 & Mantidae & 0 & 0 & 1 & 0 \\
\hline 9 & Sarcophagidae & 0 & 0 & 1 & 0 \\
\hline \multirow[t]{3}{*}{10} & Vespidae & 0 & 2 & 1 & 1 \\
\hline & Jumlah Familia & 5 & 6 & 9 & 5 \\
\hline & $\begin{array}{l}\text { Frekuensi Kehadiran } \\
\text { Musuh Alami }\end{array}$ & 30 & 19 & 24 & 18 \\
\hline
\end{tabular}

Keterangan:

P1 = Perlakuan tanpa tanaman barier dan pinggiran bersih dari gulma (kontrol)

P2 = Perlakuan dengan barier gulma yang tumbuh alami

P3 = Perlakuan barier tanaman bunga matahari

P4 = Perlakuan barier tanaman bunga kenikir 
alami tertinggi ditemukan pada perlakuan kontrol tanpa barier (P1), demikian juga dengan frekuensi kehadiran hama dan musuh alaminya. Frekuensi kehadiran hama maupun musuh alaminya yang terendah terjadi pada perlakuan barier bunga kenikir (P4). Hal ini berarti tanaman kenikir lebih menghalangi kehadiran serangga hama maupun musuh alaminya pada tajuk tanaman padi yang diberi barier tersebut, dibandingkan dengan perlakuan yang lain. Kemungkinan hal ini disebabkan karena bau bunga kenikir yang merupakan repellent bagi kehadiran serangga (Untung, 1993).

Tumbuhan berbunga menarik kedatangan serangga menggunakan karakter morfologi dan fisiologi dari bunga, yaitu ukuran, bentuk, warna, keharuman, periode berbunga, serta kandungan nektar dan pollen (Altieri \& Toledo, 2011). Kebanyakan serangga lebih menyukai bunga yang berukuran kecil, cenderung terbuka, dengan waktu berbunga yang cukup lama yang biasanya terdapat pada bunga dari famili Compositae atau Asteraceae, contohnya adalah bunga kenikir.

Populasi serangga hama dan musuh alaminya mengalami dinamika selama 1 musim tanam padi, mengikuti perkembangan tanaman padi. Pada Gambar 1, 2, 3 dan 4 berikut ini disajikan dinamika total populasi serangga hama dan musuh alaminya di setiap minggu pengamatan untuk setiap perlakuan.

Berdasar pada Gambar 1, 2, 3 dan 4 diketahui bahwa jumlah total populasi serangga hama maupun musuh alaminya mengalami dinamika di setiap minggu peng-

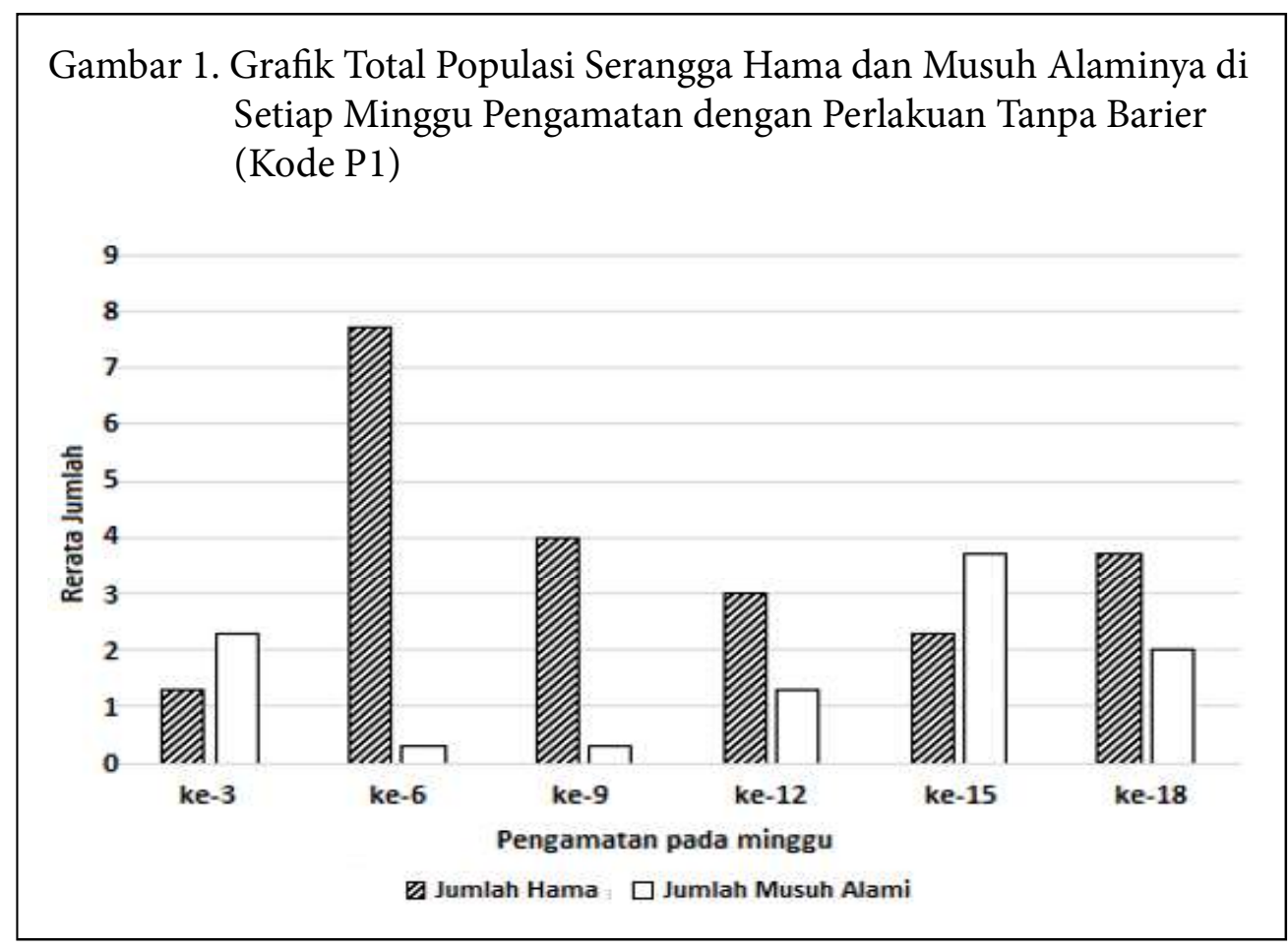



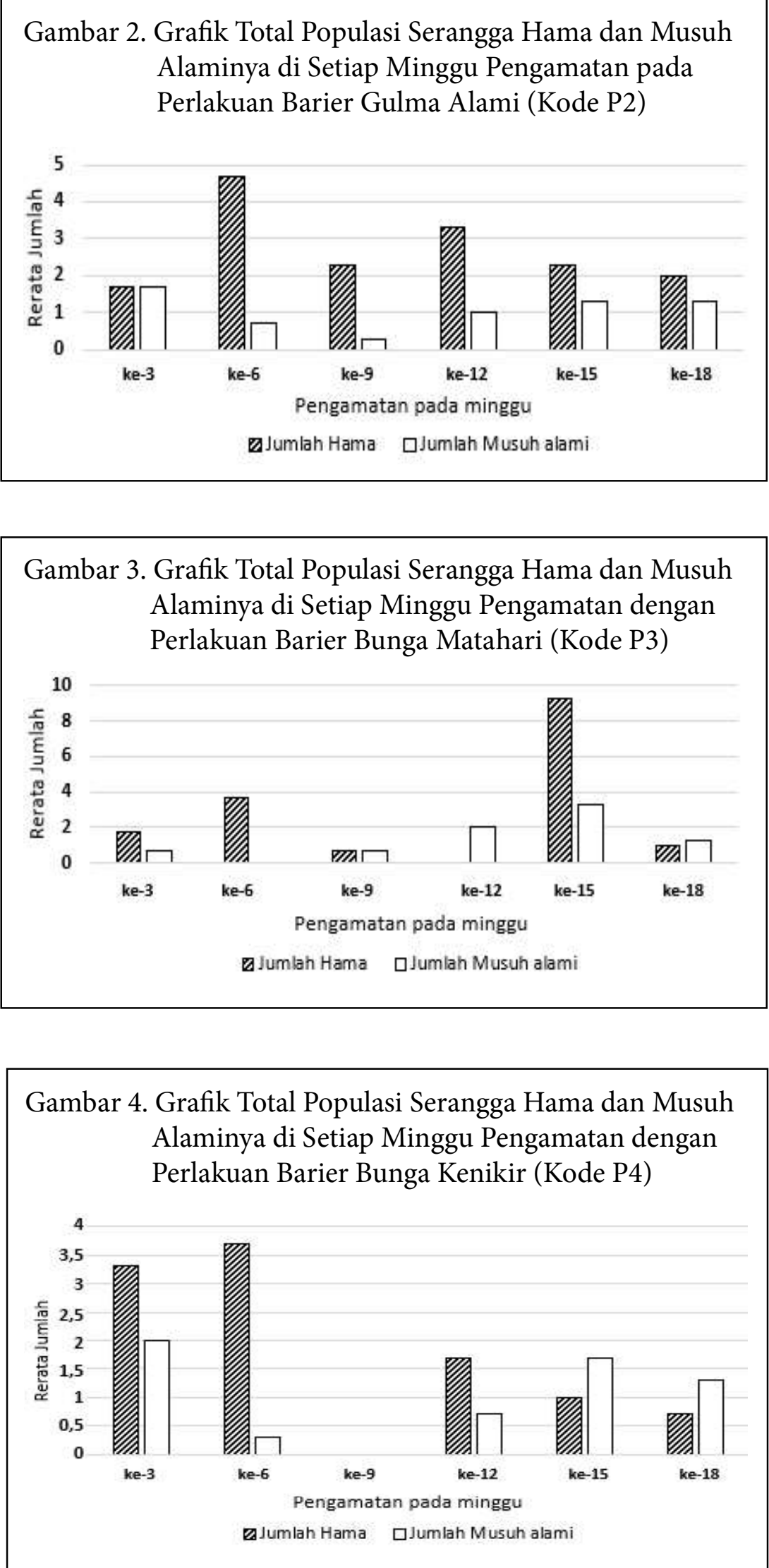
amatan, yaitu pada minggu ke-3, ke-6, ke-9, ke-12, ke-15 dan ke-18 setelah tanam. Jumlah populasi musuh alami naik turun mengikuti jumlah populasi mangsa (serangga hama). Semakin tinggi populasi hama, maka semakin tinggi pula populasi musuh alaminya. Hal ini karena predator memiliki suatu respon numerikal yang menyebabkan pertambahan jumlah populasi predator untuk menanggapi kepadatan populasi hama. Peningkatan reproduksi predator alami tergantung pada tingkat predasi. Semakin banyak mangsa yang dikonsumsi, semakin banyak energi pemangsa dapat mengalokasikannya untuk reproduksi (Rahman, Kumar, Azariah, \& Perumaisamy, 2012).

Serangga selain ditemukan pada tajuk tanaman padi, juga ada pada tajuk tanaman barier gulma alami, tanaman bunga matahari, dan tanaman bunga kenikir. Jumlah serangga yang ditemukan pada tajuk tanaman barier disajikan pada Tabel 2. Berdasarkan Tabel 2 dapat diketahui bahwa serangga hama paling banyak ditemukan pada barier gulma alami, hal ini dikarenakan gulma berpotensi dimanfaatkan sebagai tanaman penghalang/ barier bagi musuh alami. Dadi (2010) melaporkan bahwa keanekaragaman jenis gulma berpengaruh terhadap kemelimpahan arthropoda pada ekosistem sawah, baik serangga hama maupun musuh alaminya. Jenis serangga hama yang paling sedikit ditemukan adalah pada barier bunga kenikir. Hal ini disebabkan tanaman kenikir memiliki peranan sebagai repellent dan mask (penghalau), kamuflase, barier fisik dan pengendalian hayati (Altieri \& Letourneau, 1982).

Berdasarkan hasil uji beda dengan ANOVA terhadap dinamika populasi serangga hama antarperlakuan (Tabel 3) diketahui bahwa perbedaan dinamika populasi serangga hama antarperlakuan tersebut tidak signifikan. Hal ini dimungkinkan karena penelitian baru berlangsung selama 1 musim tanam. Serangga hama memerlukan pembiasaan untuk mengenali tanaman inang sebagai habitatnya (Ferdy, Gouyon, Moret, \& Godelle, 1998). Oleh karena itu, penelitian ini mungkin belum dapat menunjukkan hubungan yang signifikan dengan adanya perlakuan tanaman barier terhadap dinamika populai serangga hama pada tanaman padi. Artinya, sistem membutuhkan waktu lebih lama untuk membuktikan bahwa adanya modifikasi habitat dengan penambahan variasi tanaman barier dapat berpengaruh signifikan terhadap dinamika populasi serangga hama pada tanaman padi. Hasil panen padi per plot ulangan dari setiap perlakuan disajikan pada Tabel 4.

Berdasar pada Tabel 4 diketahui rerata hasil panen tertinggi adalah pada perlakuan P1 atau kontrol (tanpa tanaman barier dan bersih dari gulma), sedangkan terendah adalah pada perlakuan barier tanaman 
Tabel 2

Jenis-jenis Serangga Hama dan Musuh Alaminya dalam Tingkatan Takson Familia yang Ditemukan pada Tajuk Tanaman Barier di Plot-plot

Perlakuan

\begin{tabular}{|c|c|c|c|c|}
\hline \multirow{2}{*}{ No } & \multirow{2}{*}{ Familia } & \multicolumn{3}{|c|}{ Frekuensi Kehadiran dalam 1 Musim Tanam } \\
\hline & & $\mathrm{P} 2$ & P3 & P4 \\
\hline & Serangga Hama & & & \\
\hline 1 & Nymphalidae & 1 & 0 & 6 \\
\hline 2 & Curculionidae & 0 & 23 & 8 \\
\hline 3 & Carabidae & 0 & 0 & 42 \\
\hline 4 & Acrididae & 15 & 3 & 2 \\
\hline 5 & Thyreocoridae & 0 & 1 & 1 \\
\hline 6 & Crambidae & 5 & 0 & 4 \\
\hline 7 & Chrysomelidae & 22 & 1 & 0 \\
\hline 8 & Drosopillidae & 4 & 4 & 1 \\
\hline 9 & Delphacidae & 13 & 2 & 0 \\
\hline 10 & Coreidae & 0 & 7 & 0 \\
\hline 11 & Flatidae & 0 & 2 & 0 \\
\hline 12 & Pseudococcidae & 0 & 9 & 0 \\
\hline 13 & Ephydridae & 8 & 0 & 0 \\
\hline 14 & Chloropidae & 7 & 0 & 0 \\
\hline 15 & Pyralidae & 2 & 0 & 0 \\
\hline 16 & Tephritidae & 4 & 0 & 0 \\
\hline 17 & Aleyrodidae & 1 & 0 & 0 \\
\hline 18 & Ciccadellidae & 4 & 0 & 0 \\
\hline \multirow[t]{4}{*}{19} & Penthatomidae & 45 & 0 & 0 \\
\hline & Jumlah familia & 12 & 9 & 7 \\
\hline & Frekuensi Kehadiran Hama & 131 & 66 & 66 \\
\hline & Musuh Alami & & & \\
\hline 1 & Coccinelidae & 40 & 15 & 0 \\
\hline 2 & Oxyopiodae & 3 & 25 & 8 \\
\hline 3 & Formicidae & 194 & 249 & 44 \\
\hline 4 & Gryllidae & 5 & 0 & 1 \\
\hline 5 & Specidae & 0 & 22 & 4 \\
\hline 6 & Mantidae & 0 & 1 & 0 \\
\hline 7 & Tetthigonidae & 0 & 1 & 0 \\
\hline 8 & Staphylidinae & 6 & 0 & 0 \\
\hline \multirow[t]{3}{*}{9} & Ciccadidae & 2 & 0 & 0 \\
\hline & Jumlah Familia & 6 & 6 & 4 \\
\hline & Frekuensi Kehadiran Musuh Alami & 250 & 313 & 57 \\
\hline
\end{tabular}

Keterangan:

P2 = Perlakuan dengan barier gulma yang tumbuh alami

P3 = Perlakuan barier tanaman bunga matahari

P4 = Perlakuan barier tanaman bunga kenikir 
Tabel 3

Hasil Uji Beda dengan Anova terhadap Dinamika Populasi Serangga Hama pada Tajuk Tanaman Padi Antarperlakuan

\begin{tabular}{lrrrrr}
\hline & $\begin{array}{c}\text { Sum of } \\
\text { Squares }\end{array}$ & $d f$ & Mean Square & F & \multicolumn{1}{l}{ Sig. } \\
\hline Between Groups & 30,278 & 3 & 10,093 &, 806 &, 495 \\
Within Groups & 851,000 & 68 & 12,515 & & \\
\hline Total & 881,278 & 71 & & & \\
\hline
\end{tabular}

Tabel 4

Hasil Panen Berat Gabah Kering per Perlakuan

\begin{tabular}{ccccc}
\hline \multirow{2}{*}{ Perlakuan } & \multicolumn{3}{c}{ Ulangan } & $\begin{array}{c}\text { Rerata } \\
\text { (gr) }\end{array}$ \\
\cline { 2 - 4 } & Plot a (gr) & Plot b (gr) & Plot c (gr) & 50,00 \\
P1 & 80 & 50 & 20 & 25,00 \\
P2 & 30 & 20 & 25 & 11,66 \\
P3 & 10 & 15 & 10 & 26,66 \\
P4 & 25 & 30 & 25 &
\end{tabular}

Keterangan:

P1 = Perlakuan tanpa tanaman barier dan pinggiran bersih dari gulma (kontrol)

$\mathrm{P} 2=$ Perlakuan dengan barier gulma yang tumbuh alami

P3 = Perlakuan barier tanaman bunga matahari

P4 = Perlakuan barier tanaman bunga kenikir

bunga matahari. Hal ini dimungkinkan karena faktor kompetisi antara tanaman padi dan tanaman bariernya, baik dalam hal cahaya maupun unsur hara. Pada perlakuan penelitian ini dimungkinkan jarak antara tanaman barier bunga matahari dengan tanaman padi terlalu dekat sehingga akar tanaman barier berebutan unsur hara dengan tanaman padi, demikian juga tajuk tanaman barier bunga matahari mengurangi cahaya yang sampai pada tajuk tanaman padi. Akan tetapi, berdasarkan uji ANOVA diperoleh bahwa perbedaan tersebut tidak signifikan dengan nilai sig 0,082 (Tabel 5).
Berdasarkan hasil dari uji Anova dapat diketahui nilai signifikan 0,082 . Artinya, lebih besar dari 0,05 sehingga dapat diartikan bahwa perbedaan perlakuan yang diberikan tidak berpengaruh terhadap produktivitas tanaman padi yang dilihat dari hasil panen gabah kering. Dalam hal ini, kondisi iklim yang sedang kemarau panjang pada saat penelitian serta kandungan unsur hara tanah kemungkinan menjadi faktor yang paling berpengaruh terhadap produktivitas tanaman padi. Suplai nitrogen dalam tanah merupakan faktor yang sangat penting dalam kaitannya dengan pemeliharaan 
Jurnal Penelitian Saintek, Vol. 25, Nomor 1, 2020

Tabel 5

Hasil Uji Beda dengan Anova dari Hasil Panen Gabah Kering Antarplot Perlakuan

\begin{tabular}{lcrrrr}
\hline & $\begin{array}{c}\text { Sum of } \\
\text { Squares }\end{array}$ & df & Mean Square & F & \multirow{2}{*}{ Sig. } \\
\hline Between Groups & 2283,333 & 3 & 761,111 & 3,233 &, 082 \\
Within Groups & 1883,333 & 8 & 235,417 & & \\
\hline Total & 4166,667 & 11 & & & \\
\hline
\end{tabular}

atau peningkatan kesuburan tanah (Hakim, batang, cabang, dan daun. Selain itu, unsur Ismail, Mardinus, \& Muchtar, 1997). Nitroini juga berguna dalam pertumbuhan zat gen merupakan salah satu unsur hara yang cukup besar dibutuhkan oleh tanaman. Nitrogen dibutuhkan oleh tanaman untuk merangsang pertumbuhan tanaman, terutama hijau daun (klorofil), protein, lemak, dan senyawa organik lainnya. Berdasarkan hasil uji laboratorium dari sampel tanah (Tabel 6), $\mathrm{N}$ total yang ada pada perlakuan

Tabel 6

Hasil Uji Sampel Tanah dari Plot-plot Perlakuan

\begin{tabular}{clccccc}
\hline No & Parameter Uji & Satuan & P1 & P2 & P3 & P4 \\
\hline 1 & Tekstur & & & & & \\
& Pasir & $\%$ & 61 & 63 & 65 & 63 \\
& Debu & $\%$ & 30 & 27 & 28 & 28 \\
& Liat & $\%$ & 9 & 10 & 7 & 9 \\
2 & pH $\left.\mathrm{H}_{2} \mathrm{O}\right)^{*}$ & & 6,19 & 6,51 & 6,38 & 6,30 \\
3 & C-Organik* & $\%$ & 0,87 & 0,83 & 1,05 & 0,87 \\
4 & Bahan Organik & & 1,50 & 1,44 & 1,81 & 1,50 \\
5 & N-Total & $\%$ & 0,06 & 0,07 & 0,06 & 0,06 \\
6 & C/N Ratio & & 15,40 & 12,61 & 17,64 & 15,40 \\
7 & $\mathrm{~K}$-Tersedia & $\mathrm{ppm}$ & 76 & 88 & 76 & 89 \\
8 & $\mathrm{P}_{2} \mathrm{O}_{5}^{*}$ & $\mathrm{ppm}$ & 8 & 6 & 7 & 6 \\
9 & $\mathrm{P}_{2} \mathrm{O}_{5}$ potensial & $\mathrm{mg} / 100 \mathrm{gr}$ & 185 & 178 & 191 & 182 \\
10 & $\mathrm{~K}_{2} \mathrm{O}^{*}$ potensial & $\mathrm{mg} / 100 \mathrm{gr}$ & 41 & 41 & 31 & 36 \\
11 & $\mathrm{KTK}^{*}$ & $\mathrm{cmol} \mathrm{(+)kg-1}$ & 1,92 & 4,73 & 3,14 & 3,43 \\
\hline
\end{tabular}

Keterangan:

P1 = Perlakuan tanpa tanaman barier dan pinggiran bersih dari gulma (kontrol)

P2 = Perlakuan dengan barier gulma yang tumbuh alami

P3 = Perlakuan barier tanaman bunga matahari

P4 = Perlakuan barier tanaman bunga kenikir

(Sumber: Hasil Uji di Laboratorium BPTP Maguwoharjo, 2019) 
P1: 0,06\%; P2: 0,07\%; P3: 0,06\%; dan P4: $0,06 \%$ sehingga dimungkinkan bahwa jumlah $\mathrm{N}$ yang terkandung dalam tanah pada tiap plot kurang dari jumlah optimum yang dibutuhkan oleh tanaman padi. Padi gogo dapat tumbuh pada berbagai jenis tanah sehingga jenis tanah tidak begitu berpengaruh terhadap pertumbuhan dan hasil padi gogo. Oleh karena itu, dimungkinkan yang lebih berpengaruh terhadap pertumbuhan dan hasil panen adalah tingkat kesuburan tanahnya.

\section{SIMPULAN}

Kesimpulan dari penelitian ini adalah tidak terdapat perbedaan yang signifikan dari pengaruh variasijenis tanaman barier terhadap perbedaan dinamika populasi serangga hama maupun terhadap produktivitas tanaman padi, tetapi perlu diadakan penelitian lanjutan yang dikaitkan dengan variabel lain yang mempengaruhi produktivitas tanaman padi.

\section{DAFTAR PUSTAKA}

Altieri, M. A., \& Letourneau, D. K. (1982). Vegetation management and biological control in agroecosystems. Crop protection, l(4), 405-430.

Altieri, M. A., \& Toledo, V. M. (2011). The agroecological revolution in Latin America, ensuring food sovereignity and empowering peasants. J. Peasant Stud., 38, 587-612.

Dadi.(2010). Potensiagroforestripendukung eksistensi arthropoda predator wereng padi di ekosistem sawah (Disertasi tidak diterbitkan). Program Studi Ilmu-Ilmu Pertanian. Program Pasca Sarjana Fakultas Pertanian, Universitas Brawijaya, Malang.
Erdiansyah, I., \& Putri, S. U. (2018). Implementasi tanaman refugia dan peran serangga pada tanaman padi sawah (Oryza sativa) di Kabupaten Jember. Jurnal Agrin., 22(2), 123-131.

Ferdy, J. B., Gouyon, P. H., Moret, J., \& Godelle, B. (1998). Pollinator behavior and deceptive pollination: learning process and floral evolution. The American Naturalist, 152(5), 696-705.

Hakim, N., Ismail, G., Mardinus, \& Muchtar, H. (1997). Perbaikan lahan kritis dengan rotasi tanaman dalam budidaya lorong. Prosiding Simposium Penelitian Tanaman Pangan III (pp. 1656-1664) . Puslitbangtan, Deptan, Jakarta.

Horgan, F. G., Ramal, A. F., Bernal, C. C., Villegas, J. M., Stuart, A. M., \& Almazan, M. L. P. (2016). Applying ecological engineering for sustainable and resilient rice production system. Procedia Food Science, 6, 7-15.

Kurniawati, N. (2015). Keragaman dan kelimpahan musuh alami hama pada habitat padi yang dimanipulasi dengan tumbuhan berbunga. Jurnal Ilmu Pertanian, 18(1), 31-36.

Martin, P., \& Bateson, P. (1993). Measuring behaviour ( $2^{\text {nd }}$ ed.). London: Cambridge University Press.

Mustakim, A., Leksono, A. S., \& Kusuma, Z. (2014). pengaruh blok refugia terhadap pola kunjungan serangga polinator di Perkebunan Apel Poncokusumo Malang. Natural B, 2(3), 248-253.

Parolin, P., Bresch, C., Desneux, N., Brun, R., Bout, A., Boll, R., \& Poncet, C. (2012). Secondary plants used in biological control: A review. International Journal of Pest Management, 58(2), 91-100.

Rahman, J., Kumar, R., Azariah, B., \& Perumaisamy, K. (2012). Functional and numerical responses of the predatory mite, neoseiulus longispinosus, to the red spider mite, oligonychus coffeae, infesting tea. Insect Science, 12(1), 1-12.

Untung, K. (1993). Pengantar pengelolaan hama terpadu. Yogyakarta: UGM Press. 